\title{
POTENSI DAERAH DAN DAYA SAING DAERAH BERDASARKAN ANALISIS TIPOLOGI KLASSEN
}

\begin{tabular}{c} 
Andi Hendrawan \\
$\begin{array}{c}\text { Anggota Dewan Riset Daerah Kabupaten Cilacap, Dosen Akademi Maritim Nusantara } \\
\text { Cilacap, Mahasiswa Program Doktor Ilmu Manajemen UNSOED } \\
\text { andi_hendrawan@amn.ac.id }\end{array}$ \\
\hline
\end{tabular}

Diterima: Februari 2020; Disetujui: September 2020

\begin{abstract}
Regional economic competitiveness intends to obtain sustainable economic growth, namely developing superior sectors based on the potential and needs of the region whose aim is to improve people's welfare. The purpose of this study is to determine the leading sector based on GRDP in Cilacap Regency. The research method is exploratory research in the activity of compiling regional competitiveness. This is to explore the development of regional sectors by identifying and analyzing regional potentials that can be developed to improve regional competitiveness. Klassen's Typological Analysis is useful for identifying maps of macroeconomic potential. Through the Klassen Typology Analysis, regional sectoral potential based on GRDP data can be mapped. Klassen's Typological Analysis classifies a growth based on $(g)$ and the contribution of a particular sector to the total regional GRDP. Based on Klassen's typology analysis, the main sector of Cilacap Regency is the construction sector and the Large and Retail trade sector, Car and Motorcycle Repair, this is very possible because Cilacap Regency is an industrial city so that construction activities are one of Cilacap's mainstays.
\end{abstract}

Keyword: competitiveness, grdp, klassen's typology analysis

Abstraksi. Daya saing ekonomi daerah bermaksud untuk mendapatkan pertumbuhan ekonomi yang berkelanjutan, yaitu mengembangkan sektor-sektor yang unggul berdasarkan potensi dan kebutuhan daerah yang tujuannya meningkatkan kesejahteraan rakyat.. Tujuan penelitian ini adalah menentukan sektor unggulan berdasarkan PDRB di Kabupaten Cilacap. Metode penelitian adalah penelitian eksploratif dalam kegiatan menyusun daya saing daerah ini adalah mengeksplorasi pengembangan sektor daerah dengan mengidentifikasi dan menganalisis potensi daerah yang dapat dikembangkan untuk meningkatkan daya saing daerah. Analisis Tipologi Klassen berguna untuk mengidentifikasi peta potensi ekonomi makro. Melalui Analisis Tipologi Klassen, potensi regional sektoral berdasarkan data PDRB dapat dipetakan. Analisis Tipologi Klassen mengklasifikasikan suatu berdasarkan pertumbuhan $(g)$ dan kontribusi sektor tertentu terhadap total PDRB daerah. Berdasarkan analisis tipologi klassen, sektor unggulan Kabupaten Cilacap adalah sektor konstruksi dan sektor perdagangan Besar dan Eceran, Perbaikan Mobil dan Motor, hal ini sangat dimungkinkan karena Kabupaten Cilacap merupakan kota industri sehingga kegiatan konstruksi menjadi salah satu andalan Cilacap.

Kata kunci: daya saing, pdrb, analisis tipologi klassen

\section{PENDAHULUAN}

Pembangunan yang mampu memenuhi kebutuhan manusia secara berkelanjutan merupakan pembangunan yang bertujuan untuk memenuhi kebutuhan masa kini tanpa melupakan kemampuan manusia dalam mencukupi kebutuhan mereka di masa yang akan datang. Konsep pembangunan 
berkelanjutan ini, kini sudah menjadi tujuan dalam pembangunan dan pengembangan kota dan kabupaten di Indonesia. Dalam menciptakan kota dan kabupaten yang berkelanjutan, diperlukan lima prinsip dasar, yaitu environment (ecology), economy (employment), equity, engagement and energy (Irawati, $\mathrm{U}$, Resobeoen, $\mathrm{S}, \&$ Aryanto, 2012)

Tujuan dari daya saing ekonomi daerah untuk memberikan pertumbuhan ekonomi yang berkelanjutan, antara lain dikembangkannya sektor unggulan sesuai dengan potensi dan kebutuhan daerah dalam rangka peningkatan kesejahteraan masyarakat. Hal ini sejalan dengan pelaksanaan otonomi daerah dan desentralisasi fiskal, Pemerintah daerah berperan dalam mengupayakan peningkatan daya saing daerah menjadi hal yang sangat penting dan strategis.

Pemerintah daerah dalam pelaksanaan otonomi daerah meliputi (1) keselarasan dan (2) keserasian. Menyelaraskan dalam pemberian pelayanan dan meningkatkan peran serta, prakarsa dan pemberdayaan masyarakat yang memperhatikan kepentingan dan aspirasi masyarakat. Serasi dalam penyelenggaraan hubungan antar tingkat pemerintahan, baik antar daerah maupun antara pusat dan daerah. Instrumen utama dalam pelaksanaan desentralisasi fiskal adalah pendanaan atas penyerahan urusan kepada daerah secara proporsional, adil, demokratis dan transparan dengan memperhatikan potensi dan kebutuhan daerah. Pelaksanaan desentralisasi fiskal bermakna pada pengelolaan keuangan secara efektif, efisien dan akuntabel dalam rangka mendukung pelayanan publik (Bapeda Kab Banyuwangi, 2015)

Pembangunan ekonomi daerah merupakan suatu proses ketika pemerintah daerah dan seluruh komponen masyarakat menggunakan berbagai sumber daya yang dimiliki dan membentuk suatu pola kemitraan guna menciptakan lapangan pekerjaan baru dan membuat triger (pemicu) perkembangan kegiatan ekonomi daerah tersebut (Arsyad, 2001). Pertumbuhan ekonomi dapat diukur dari keberhasilan pertumbuhan ekonomi, struktur ekonomi dan kecilnya ketimpangan pendapatan antar penduduk, antar daerah dan antar sektor (Ariyanto, 2013).

Beberapa tahun terakhir, banyak perubahan yang terjadi pada perangkat global dan lokal yang sangat berpengaruh terhadap perekonomian nasional. Krisis finansial global yang terjadi pada tahun 2008, Perdagangan bebas yang diterapkan antara China-ASEAN (CAFTA), perubahan sistem pencatatan perdagangan internasional dan meluasnya jasa layanan pasar modal adalah contoh perubahan yang perlu penyesuaian dalam mekanisme pencatatan statistik nasional.

Bentuk penyesuaian pencatatan statistik nasional adalah melakukan perubahan tahun dasar PDB Indonesia dari tahun $2000 \mathrm{ke}$ 2010. Melakukan perubahan tahun dasar PDB seiring dengan pengadopsian rekomendasi Perserikatan Bangsa-Bangsa (PBB) yang tertuang dalam System of National Accounts (SNA 2008) melalui penyusunan kerangka Supply and Use Tables (SUT). Perubahan tahun dasar PDB dilakukan secara bersamaan dengan perhitungan Produk Domestik Regional Bruto (PDRB) Provinsi agar konsistensi hasil penghitungan terjaga. Pada tahun dasar juga diiringi dengan perubahan kategori lapangan usaha dari 9 sektor menjadi 17 kategori.

Daya saing (competitiveness) adalah sebuah konsep multidimensional. Terdapat tiga tingkatan yang berbeda: negara 
(country), industri dan tingkat perusahaan. Berdasarkan istilah kata "daya saing (competitiveness)" berasal dari bahasa Latin, competer, yang berarti keterlibatan dalam pasar persaingan. Daya saing adalah kata untuk menjelaskan kekuatan ekonomi dari sebuah lembaga yang bertarung dalam persaingan ekonomi pasar global yang mana barang, jasa, penduduk, keahlian dan ide bergerak dengan bebas melintasi perbatasan geografi (Muth, 1998).

Tingkat daya saing perusahaan (firm level competitiveness) didefinisikan sebagai kemampuan perusahaan dalam mendesain, memproduksi dan atau menghasilkan produk pasar yang unggul terhadap barang yang ditawarkan oleh pesaing, dalam hal mutu harga dan non harga (Rajagukguk, 2018).

\section{Struktur Ekonomi}

Pada lima tahun terakhir (2013 - 2017), struktur ekonomi Kabupaten Cilacap berdasarkan PDRB Atas Dasar Harga Berlaku dengan minyak dan lapangan usaha yang memberikan andil besar adalah lapangan usaha Pertanian, lapangan usaha Industri Pengolahan dan kehutanan dan Perikanan. Usaha lain yang memberikan andil pada kisaran 5 persen antara lain Konstruksi dan Perdagangan Besar dan Eceran, Reparasi Mobil dan Sepeda Motor yang menempati posisi ketiga dan keempat adapun sektor-sektor lain kontribusinya berkisar 3 persen atau kurang.

Tabel 1.

Distribusi Persentase PDRB Kabupaten Cilacap Menurut Lapangan Usaha Atas Dasar Harga Berlaku Dengan Minyak

Tahun 2013- 2017 (persen)

\begin{tabular}{clrrrrr}
\hline & Kategori/Lapangan Usaha & 2013 & 2014 & 2015 & $\left.2016^{*}\right)$ & $2017^{* * *}$ \\
& & \multicolumn{1}{c}{$(1)$} & \multicolumn{1}{c}{$(3)$} & \multicolumn{1}{c}{$(4)$} & \multicolumn{1}{c}{$(5)$} & \multicolumn{1}{c}{$(6)$} \\
\hline A & Pertanian, Kehutanan dan Perikanan & 8,76 & 8,46 & 8,82 & 9,41 & 9,23 \\
B & Pertambangan dan Penggalian & 2,38 & 3,26 & 3,52 & 3,74 & 3,66 \\
C & Industri Pengolahan & 69,34 & 67,81 & 66,48 & 63,63 & 63,15 \\
D & Pengadaan Listrik dan Gas & 0,05 & 0,05 & 0,06 & 0,07 & 0,08 \\
E & Pengadaan Air, Pengelolaan Sampah, & 0,04 & 0,04 & 0,03 & 0,03 & 0,03 \\
& Limbah dan Daur Ulang & & & & & \\
F & Konstruksi & 4,73 & 4,91 & 5,16 & 5,71 & 5,80 \\
G & Perdagangan Besar dan Eceran; & 4,92 & 5,04 & 5,11 & 5,57 & 5,79 \\
& Reparasi Mobil dan Sepeda Motor & & & & & \\
H & Transportasi dan Pergudangan & 2,19 & 2,38 & 2,64 & 2,94 & 3,01 \\
I & Penyediaan Akomodasi dan Makan & 0,91 & 0,98 & 1,02 & 1,12 & 1,15 \\
& Minum & & & & & \\
J & Informasi dan Komunikasi & 1,23 & 1,36 & 1,34 & 1,44 & 1,55 \\
K & Jasa Keuangan dan Asuransi & 0,81 & 0,85 & 0,89 & 0,99 & 1,03 \\
L & Real Estate & 0,73 & 0,79 & 0,82 & 0,89 & 0,92 \\
M,N & Jasa Perusahaan & 0,13 & 0,14 & 0,15 & 0,17 & 0,17 \\
O & Administrasi Pemerintahan, & 1,16 & 1,15 & 1,17 & 1,26 & 1,26 \\
& Pertahanan dan Jaminan Sosial Wajib & & & & & \\
\hline
\end{tabular}




\begin{tabular}{clrrrrr}
\hline & Kategori/Lapangan Usaha & 2013 & 2014 & 2015 & $2016^{*}$ & $\left.2017^{* *}\right)$ \\
& & $(2)$ & \multicolumn{1}{c}{$(3)$} & \multicolumn{1}{c}{$(4)$} & \multicolumn{1}{c}{$(5)$} & \multicolumn{1}{c}{$(6)$} \\
\hline P & Jasa Pendidikan & 1,65 & 1,72 & 1,70 & 1,84 & 1,93 \\
Q & Jasa Kesehatan dan Kegiatan Sosial & 0,31 & 0,35 & 0,36 & 0,40 & 0,43 \\
R,S,T,U & Jasa lainnya & 0,65 & 0,71 & 0,72 & 0,78 & 0,80 \\
& PDRB & 100,00 & 100,00 & 100,00 & 100,00 & 100,00 \\
\hline
\end{tabular}

Sumber: Badan Pusat Statistik Kabupaten Cilacap, 2018

*) Angka Sementara, **) Angka Sangat Sementara

PDRB Kabupaten Cilacap atas Dasar Harga Berlaku tanpa minyak, kurun waktu lima tahun terakhir adalah masih dari lapangan usaha Industri Pengolahan. Tabel.1 memperlihatkan bahwa tahun 2017 Industri Pengolahan memberikan sumbangan terbesar terhadap pembentukan PDRB Kabupaten Cilacap yaitu sebesar 31,96 persen. Lapangan usaha lainnya yang yang memberikan sumbangan cukup besar setelah Industri Pengolahan adalah lapangan Konstruksi dan Perdagangan Besar dan Eceran, Reparasi Mobil dan Sepeda Motor, usaha Pertanian, Kehutanan dan Perkebunan, dimana masing-masing memberikan sumbangan sebesar 17,05 persen, 10,70 dan 10,69 persen.

Tabel 2.

Distribusi Persentase PDRB Kabupaten Cilacap Menurut Lapangan Usaha Atas Dasar Harga Berlaku Tanpa Minyak

Tahun 2013- 2017 (persen)

\begin{tabular}{llrrrrr}
\hline & Kategori/Lapangan Usaha & 2013 & 2014 & 2015 & $\left.2016^{*}\right)$ & $\left.2017^{* *}\right)$ \\
& & \multicolumn{1}{c}{$(1)$} & \multicolumn{1}{c}{$(3)$} & \multicolumn{1}{c}{$(4)$} & \multicolumn{1}{c}{$(5)$} & \multicolumn{1}{c}{$(6)$} \\
\hline A & $\begin{array}{l}\text { Pertanian, Kehutanan dan } \\
\text { Perikanan }\end{array}$ & 18,83 & 17,53 & 17,78 & 17,50 & 17,05 \\
B & Pertambangan dan Penggalian & 5,13 & 5,76 & 7,11 & 6,95 & 6,76 \\
C & Industri Pengolahan & 34,06 & 33,31 & 32,41 & 32,35 & 31,96 \\
D & Pengadaan Listrik dan Gas & 0,10 & 0,12 & 0,12 & 0,13 & 0,15 \\
E & Pengadaan Air, Pengelolaan & 0,08 & 0,07 & 0,07 & 0,07 & 0,06 \\
& Sampah, Limbah dan Daur Ulang & & & & & \\
F & Konstruksi & 10,18 & 10,17 & 10,39 & 10,63 & 10,70 \\
G & Perdagangan Besar dan Eceran; & 10,58 & 10,44 & 10,30 & 10,35 & 10,69 \\
& Reparasi Mobil dan Sepeda Motor & & & & & \\
H & Transportasi dan Pergudangan & 4,70 & 4,93 & 5,33 & 5,46 & 5,57 \\
I & Penyediaan Akomodasi dan Makan & 1,97 & 2,04 & 2,06 & 2,09 & 2,13 \\
& Minum & & & & & \\
J & Informasi dan Komunikasi & 2,64 & 2,82 & 2,69 & 2,68 & 2,87 \\
\hline
\end{tabular}




\begin{tabular}{clccccc}
\hline & Kategori/Lapangan Usaha & 2013 & 2014 & 2015 & $\left.2016^{*}\right)$ & $\left.2017^{* *}\right)$ \\
& & $(2)$ & $(3)$ & $(4)$ & $(5)$ & $(6)$ \\
\hline K & Jasa Keuangan dan Asuransi & 1,75 & 1,75 & 1,79 & 1,84 & 1,90 \\
L & Real Estate & 1,58 & 1,64 & 1,66 & 1,66 & 1,71 \\
M,N & Jasa Perusahaan & 0,29 & 0,30 & 0,31 & 0,31 & 0,32 \\
O & Administrasi Pemerintahan, & 2,49 & 2,38 & 2,36 & 2,34 & 2,32 \\
& Pertahanan dan Jaminan Sosial & & & & & \\
& Wajib & & & & & \\
P & Jasa Pendidikan & 3,55 & 3,56 & 3,42 & 3,43 & 3,56 \\
Q & Jasa Kesehatan dan Kegiatan Sosial & 0,66 & 0,72 & 0,73 & 0,75 & 0,79 \\
R,S,T, & Jasa lainnya & 1,41 & 1,47 & 1,45 & 1,45 & 1,48 \\
U & & & & & & \\
\hline & PDRB & 100,00 & 100,00 & 100,00 & 100,00 & 100,00 \\
\hline
\end{tabular}

Sumber: Badan Pusat Statistik Kabupaten Cilacap, 2018

*) Angka sementara, **) Angka Sangat Sementara

\section{Pertumbuhan Ekonomi}

Tabel 3. menunjukkan laju pertumbuhan ekonomi tanpa minyak dan dengan minyak di Kabupaten Cilacap selama kurun waktu 5 tahun (2013 - 2018). Pada tahun 2013 laju pertumbuhan ekonomi Kabupaten Cilacap sebesar 5,25 persen. Pada tahun 2014 pertumbuhan sebesar 5,34 persen, tahun 2015 sebesar 5,55 persen, tahun 2016 menjadi sebesar 5,01 persen, sementara tahun 2017 pertumbuhan ekonomi mengalami sedikit pertumbuhan menjadi sebesar 5,03 persen. Laju pertumbuhan ekonomi dengan minyak tahun 2017 sebesar 2,45 persen. Laju pertumbuhan ini melambat dibandingkan dengan tahun 2016 yang tumbuh sebesar 5,06 persen. Laju pertumbuhan ekonomi dengan migas Kabupaten Cilacap sangat dipengaruhi oleh produksi industri minyak, dimana kontribusi industri minyak terhadap PDRB secara total mempunyai andil yang cukup besar.

Tabel 3.

Pertumbuhan Ekonomi Kabupaten Cilacap Tahun 2013- 2017 (persen)

\begin{tabular}{ccc}
\hline T a h u & Dengan Minyak & Tanpa Minyak \\
\hline$(1)$ & $(2)$ & $(3)$ \\
\hline 2013 & 1,66 & 5,25 \\
2014 & 2,92 & 5,34 \\
2015 & 5,94 & 5,55 \\
$\left.2016^{*}\right)$ & 5,06 & 5,01 \\
$\left.2017^{* *}\right)$ & 2,45 & 5,03 \\
\hline
\end{tabular}

Sumber: Badan Pusat Statistik Kabupaten Cilacap, 2018

*) Angka sementara, **) Angka Sangat Sementara 


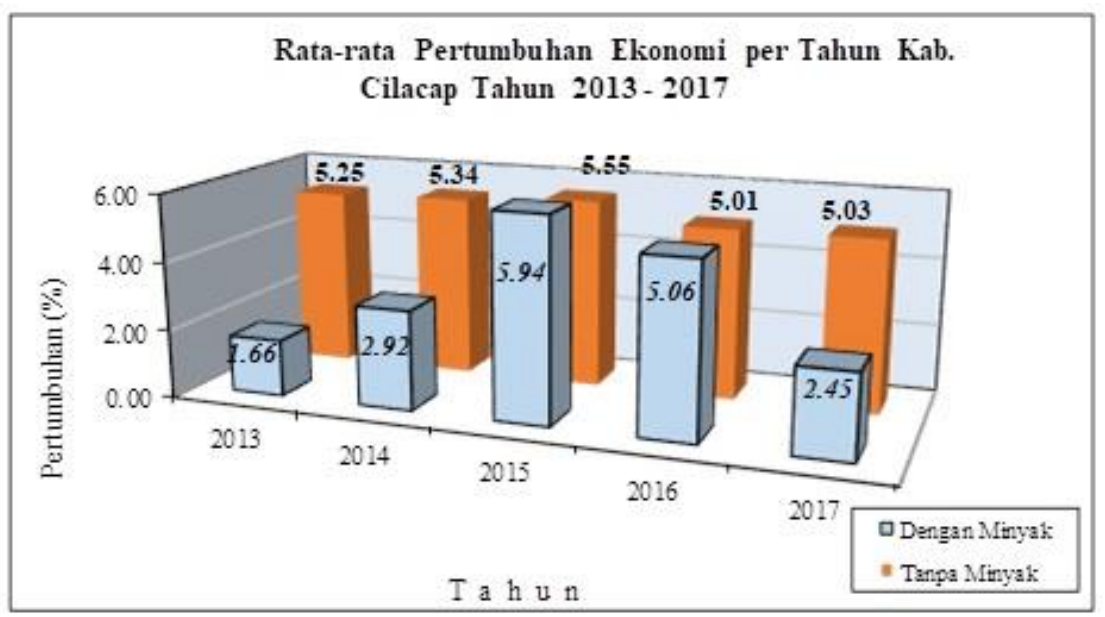

Gambar 1. Grafik pertumbuhan ekonomi

Sumber: Badan Pusat Statistik Kabupaten Cilacap, 2018

Secara sektoral, pertumbuhan (tanpa juga mengalami pertumbuhan cukup tinggi migas) tertinggi terjadi pada lapangan usaha yaitu Pengadaan Listrik, Gas dan Jasa Informasi dan Komunikasi (10,71 persen) Kesehatan dan Kegiatan Sosial yang dan terendah Pertambangan dan Penggalian masing-masing tumbuh sebesar 9,04 (1,92 persen). Lapangan usaha lain yang persen dan 9,71 persen.

Tabel 4.

Pertumbuhan Ekonomi Menurut Lapangan Usaha di Kabupaten Cilacap Tahun 2013 - 2017 Tanpa Minyak (persen)

\begin{tabular}{llrrrrr}
\hline & Kategori/Lapangan Usaha & 2013 & 2014 & 2015 & $\left.2016^{*}\right)$ & $\left.2017^{*}\right)$ \\
\hline & \multicolumn{1}{c}{$(1)$} & \multicolumn{1}{c}{$(2)$} & \multicolumn{1}{c}{$(3)$} & \multicolumn{1}{c}{$(4)$} & \multicolumn{1}{c}{$(5)$} & \multicolumn{1}{c}{$(6)$} \\
\hline A & Pertanian, Kehutanan dan & 3,19 & $-2,65$ & 6,22 & 3,10 & 2,75 \\
& Perikanan & & & & & \\
B & Pertambangan dan Penggalian & 7,04 & 25,32 & 0,33 & 0,08 & 1,92 \\
C & Industri Pengolahan & 6,09 & 3,45 & 3,76 & 4,53 & 3,79 \\
D & Pengadaan Listrik dan Gas & 10,45 & 20,90 & 13,39 & 9,30 & 9,04 \\
E & Pengadaan Air, Pengelolaan & 0,40 & 4,33 & 0,10 & 2,04 & 5,76 \\
& Sampah, Limbah dan Daur & & & & & \\
& Ulang & & & & & \\
F & Konstruksi & 2,75 & 4,51 & 7,14 & 9,03 & 6,92 \\
G & Perdagangan Besar dan Eceran; & 3,45 & 6,31 & 6,08 & 6,61 & 7,59 \\
& Reparasi Mobil dan Sepeda & & & & & \\
& Motor & & & & & \\
H & Transportasi dan Pergudangan & 11,80 & 9,98 & 9,85 & 4,55 & 5,08 \\
I & Penyediaan Akomodasi dan & 4,19 & 10,31 & 7,32 & 4,77 & 6,00 \\
& Makan Minum & & & & & \\
\hline
\end{tabular}




\begin{tabular}{clrrrrr}
\hline J & Informasi dan Komunikasi & 5,39 & 18,37 & 13,04 & 6,92 & 10,71 \\
K & Jasa Keuangan dan Asuransi & 4,01 & 5,92 & 7,60 & 8,41 & 7,07 \\
L & Real Estate & 8,21 & 11,54 & 7,37 & 6,08 & 7,52 \\
M,N & Jasa Perusahaan & 14,13 & 10,17 & 9,72 & 7,64 & 8,14 \\
O & Administrasi Pemerintahan, & 2,52 & 1,72 & 6,36 & 2,41 & 3,73 \\
& Pertahanan dan Jaminan Sosial & & & & & \\
& Wajib & & & & & \\
P & Jasa Pendidikan & 7,94 & 7,23 & 4,04 & 6,92 & 7,22 \\
Q & Jasa Kesehatan dan Kegiatan & 8,75 & 14,65 & 9,39 & 10,11 & 9,71 \\
& Sosial & & & & & \\
R,S,T,U & Jasa lainnya & 10,06 & 8,37 & 4,05 & 6,22 & 8,32 \\
& Pertumbuhan PDRB Kab. & 5,25 & 5,34 & 5,55 & 5,01 & 5,03 \\
\hline
\end{tabular}

Sumber: Badan Pusat Statistik Kabupaten Cilacap, 2018

*) Angka sementara

\section{METODE PENELITIAN}

\section{Rancangan Kegiatan}

Rancang penelitian merupakan sebuah kerangka pikir dan kerja yang dipergunakan dalam melakukan sebuah penelitian (Malhotra, 2004). Kerangka kerja memberi spesifikasi prosedur yang dipergunakan untuk memperoleh informasi yang dibutuhkan guna menstrukturkan dan menjawab permasalahan penelitian. Kegiatan penelitian ini menggunakan rancangan penelitian deskriptif eksploratif. Riset deskriptif eksploratif pernah dilakukan oleh Bappeda Banyuwangi. (Bappeda Kabupaten Banyuwangi, 2015).

Kegiatan eksploratif Riset dalam penyusunan daya saing daerah merupakan eksplorasi mengenai perkembangan sektoral daerah dengan mengidentifikasi dan menganalisis potensi-potensi yang dimiliki oleh daerah yang dapat dikembangkan bagi peningkatan daya saing daerah.

\section{Sumber Data}

Data yang digunakan dalam penelitian berasal dari sumber data sekunder dan sumber data primer. Data sekunder adalah data-data yang berasal dari berbagai literatur kepustakaan, artikel dalam majalah, jurnal penelitian yang berkaitan dan sumber media massa lainnya serta hasil penelitian terdahulu. Data sekunder yang digunakan dalam penelitian berasal dari data laporan tahunan dari pihak-pihak terkait seperti: Badan Perencanaan Pembangunan Penelitian dan Pengembangan Daerah (Bappelitbangda) dan Badan Pusat Statistik.

\section{Metode Pengumpulan Data}

Dalam pelaksanaan kegiatan ini akan dilakukan beberapa kegiatan, meliputi: Kajian Pustaka dan Survei Tahap inventarisasi data/informasi sekunder, yakni mengumpulkan data/informasi dari berbagai laporan hasil penelitian terdahulu yang terkait dengan daya saing daerah dan berbagai studi-studi yang relevan. Tahap inventarisasi data/informasi primer, yakni pengumpulan data/informasi yang diperoleh secara langsung melalui wawancara dan observasi (pengamatan lapangan). 


\section{Teknik Analisa Data}

Teknik analisa data yang digunakan dalam penelitian ini menggunakan analisa deskriptif dan analisa tipologi klassen. Analisis Tipologi Klassen Potensi perekonomian daerah dapat dilihat dari sisi pertumbuhan ekonominya dan kontribusi sektoral terhadap PDRB-nya. Pemetaan potensi perekonomian khususnya di sembilan sektor lapangan usaha akan sangat bermanfaat bagi daerah untuk membuat prioritas kebijakan. Untuk menentukan prioritas kebijakan ini, khususnya kebijakan pembangunan ekonomi, diperlukan analisis ekonomi (struktur ekonomi) daerah secara menyeluruh. Analisis ekonomi yang digunakan adalah tipologi klassen. Analisis tipologi klassen dipergunakan untuk mengidentifikasi peta potensi ekonomi secara makro. Berdasarkan analisis Tipologi Klassen, potensi daerah secara sektoral yang didasarkan pada data PDRB bisa dipetakan. Analisis tipologi klassen mengelompokkan suatu sektor dengan mempertimbangkan pertumbuhan $(\mathrm{g})$ dan kontribusi sektor (s) tertentu terhadap total PDRB suatu daerah. Analisis Tipologi Klassen dipergunakan untuk mengelompokkan masing-masing sektor ke dalam empat kategori dapat dilihat di tabel 5, yaitu:

Tabel 5.Matriks Kategori Sektor berdasarkan Tipologi Klassen

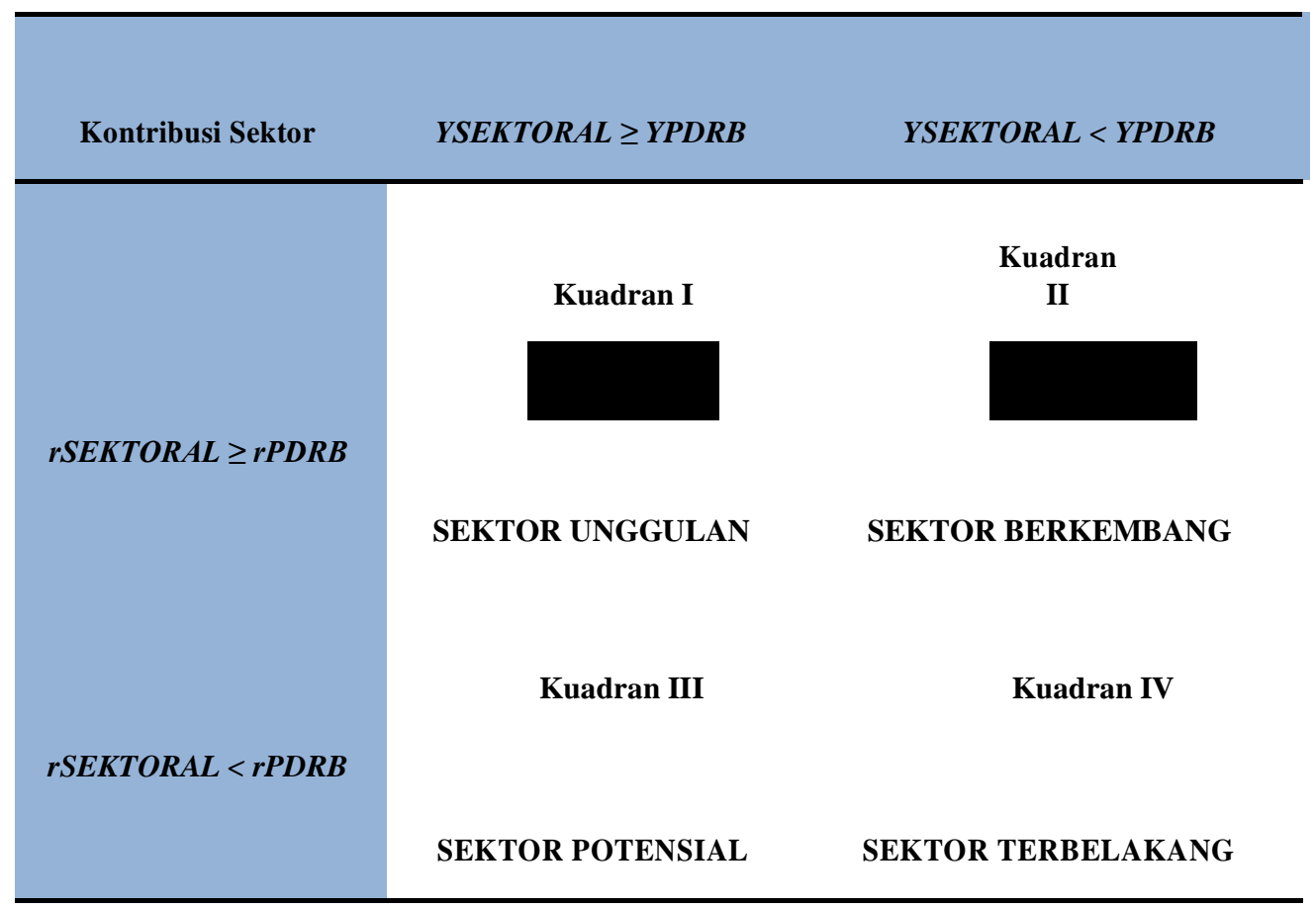

Sumber: Bappeda Kabupaten Banyuwangi, 2015

Sektor Unggulan / Prima (Kuadran I). dilambangkan dengan gi lebih besar dari $\boldsymbol{g}$ Kuadran ini merupakan kuadran dengan dan si lebih besar dari $\boldsymbol{s}$.

laju pertumbuhan sektor yang lebih besar dibandingkan pertumbuhan daerah (PDRB) dan memiliki kontribusi besar terhadap PDRB. Pada sektor unggulan ini
Sektor berkembang (Kuadran II). Sektor yang berada pada kuadran ini, nilai pertumbuhan sektor yang lebih tinggi dibandingkan dengan pertumbuhan PDRB, namun nilai kontribusi terhadap PDRB 
daerah yang lebih kecil. Sektor pertumbuhan sektor (gi) yang lebih rendah berkembang ditunjukkan dengan gi lebih kecil dari $\boldsymbol{g}$ dan si lebih besar dari s. Sektor dalam kategori ini merupakan sektor yang telah jenuh.

Sektor potensial atau masih dapat berkembang dengan pesat (Kuadran III). Pada kuadran ditunjukkan dengan sektor yang memiliki pertumbuhan sektor (gi) yang lebih rendah dari pertumbuhan PDRB $(g)$, tetapi kontribusi sektor tersebut terhadap PDRB (si) lebih kecil. Sektor potensial merupakan sektor yang sedang booming.

Sektor Terbelakang (Kuadran IV). Pada kuadran ini sektor terbelakang memiliki dibandingkan pertumbuhan PDRB daerah (g) serta sekaligus memiliki kontribusi lebih kecil terhadap PDRB (si).

\section{HASIL ANALISIS TIPOLOGI KLASSEN}

Dalam upaya untuk membangun suatu daerah, menurut teori pertumbuhan jalur cepat (turnpike), setiap wilayah penting untuk melihat sektor/komoditi apa yang memiliki potensi besar dan dapat dikembangkan dengan cepat. Sektor potensial dapat diketahui dengan menggunakan hasil perhitungan analisis tipologi klassen.

Tabel 6.

Laju Pertumbuhan PDRB Kabupaten Cilacap Atas Dasar Harga Konstan 2010 Menurut Lapangan Usaha (Persen), 2015-2017

\begin{tabular}{|c|c|c|c|c|c|}
\hline Kategori & Uraian & 2015 & 2016 & 2017 & $\begin{array}{c}\text { Perbandingan } \\
\text { Dengan Laju } \\
\text { Pertumbuhan } \\
\text { PDRB }\end{array}$ \\
\hline A & $\begin{array}{l}\text { Pertanian, Kehutanan dan } \\
\text { Perikanan }\end{array}$ & 6.22 & 3.10 & 2.15 & Lebih kecil \\
\hline B & Pertambangan dan Penggalian & 0.33 & 0.08 & 1.92 & Lebih kecil \\
\hline $\mathrm{C}$ & Industri Pengolahan & 5.76 & 4.99 & 1.11 & Lebih kecil \\
\hline $\mathrm{D}$ & Pengadaan Listrik dan Gas & 13.39 & 9.30 & 9.04 & Lebih besar \\
\hline $\mathrm{E}$ & $\begin{array}{l}\text { Pengadaan Air, Pengelolaan } \\
\text { Sampah, Limbah dan Daur } \\
\text { Ulang }\end{array}$ & 0.10 & 2.04 & 5.76 & Lebih besar \\
\hline $\mathrm{F}$ & Konstruksi & 7.14 & 9.03 & 6.92 & Lebih besar \\
\hline $\mathrm{G}$ & $\begin{array}{l}\text { Perdagangan Besar dan Eceran, } \\
\text { Reparasi Mobil dan Sepeda } \\
\text { Motor }\end{array}$ & 6.08 & 6.61 & 7.59 & Lebih besar \\
\hline $\mathrm{H}$ & Transportasi dan Pergudangan & 9.85 & 4.55 & 5.08 & Lebih besar \\
\hline I & $\begin{array}{l}\text { Penyediaan Akomodasi dan } \\
\text { Makan Minum }\end{array}$ & 7.32 & 4.77 & 6.00 & Lebih besar \\
\hline $\mathrm{J}$ & Informasi dan Komunikasi & 13.04 & 6.92 & 10.71 & Lebih besar \\
\hline
\end{tabular}




\begin{tabular}{|c|c|c|c|c|c|}
\hline K & Jasa Keuangan dan Asuransi & 7.60 & 8.41 & 7.07 & Lebih besar \\
\hline $\mathrm{L}$ & Real Estate & 7.37 & 6.08 & 7.52 & Lebih besar \\
\hline $\mathrm{M}, \mathrm{N}$ & Jasa Perusahaan & 9.72 & 7.64 & 8.14 & Lebih besar \\
\hline $\mathrm{O}$ & $\begin{array}{l}\text { Administrasi Pemerintah, } \\
\text { Pertahanan dan Jaminan Sosial } \\
\text { Wajib }\end{array}$ & 6.36 & 2.41 & 3.73 & Lebih besar \\
\hline $\mathrm{P}$ & Jasa Pendidikan & 4.04 & 6.92 & 7.22 & Lebih besar \\
\hline Q & $\begin{array}{l}\text { Jasa Kesehatan dan Kegiatan } \\
\text { Sosial }\end{array}$ & 9.39 & 10.11 & 9.71 & Lebih besar \\
\hline $\mathrm{R}, \mathrm{S}, \mathrm{T}, \mathrm{U}$ & Jasa Lainnya & 4.05 & 6.22 & 8.32 & Lebih besar \\
\hline $\begin{array}{l}\text { PRODUK } \\
\text { BRUTO }\end{array}$ & DOMESTIK REGIONAL & 5.96 & 5.06 & 2.45 & \\
\hline
\end{tabular}

Sumber: Badan Pusat Statistik Kabupaten Cilacap, 2018, data diolah Tabel 7.

Distribusi PDRB Kabupaten Cilacap Atas Dasar Harga Konstan 2010 Menurut Lapangan Usaha (Persen), 2015-2017

\begin{tabular}{|c|c|c|c|c|c|}
\hline Kategori & Uraian & 2015 & 2016 & 2017 & $\begin{array}{c}\text { Perbandingan } \\
\text { Dengan } \\
\text { Distribusi } \\
\text { PDRB }\end{array}$ \\
\hline $\mathrm{A}$ & Pertanian, Kehutanan dan Perikanan & 16.54 & 16.24 & 15.89 & Lebih besar \\
\hline B & Pertambangan dan Penggalian & 6.06 & 5.77 & 5.60 & Lebih kecil \\
\hline $\mathrm{C}$ & Industri Pengolahan & 32.51 & 32.36 & 31.98 & Lebih besar \\
\hline $\mathrm{D}$ & Pengadaan Listrik dan Gas & 0.15 & 0.16 & 0.17 & Lebih kecil \\
\hline $\mathrm{E}$ & $\begin{array}{l}\text { Pengadaan Air, Pengelolaan } \\
\text { Sampah, Limbah dan Daur Ulang }\end{array}$ & 0.08 & 0.08 & 0.08 & Lebih kecil \\
\hline $\mathrm{F}$ & Konstruksi & 10.32 & 10.72 & 10.91 & Lebih besar \\
\hline G & $\begin{array}{l}\text { Perdagangan Besar dan Eceran, } \\
\text { Reparasi Mobil dan Sepeda Motor }\end{array}$ & 11.27 & 11.44 & 11.72 & Lebih besar \\
\hline $\mathrm{H}$ & Transportasi dan Pergudangan & 5.75 & 5.73 & 5.73 & Lebih kecil \\
\hline I & $\begin{array}{l}\text { Penyediaan Akomodasi dan Makan } \\
\text { Minum }\end{array}$ & 2.18 & 2.18 & 2.20 & Lebih kecil \\
\hline $\mathrm{J}$ & Informasi dan Komunikasi & 3.66 & 3.73 & 3.93 & Lebih kecil \\
\hline K & Jasa Keuangan dan Asuransi & 1.71 & 1.77 & 1.80 & Lebih kecil \\
\hline
\end{tabular}




\begin{tabular}{clcccc}
\hline L & Real Estate & 1.89 & 1.91 & 1.95 & Lebih kecil \\
M,N & Jasa Perusahaan & 0.31 & 0.32 & 0.33 & Lebih kecil \\
& $\begin{array}{l}\text { Administrasi Pemerintah, } \\
\text { O }\end{array}$ & & & & \\
$\quad$ & $\begin{array}{l}\text { Pertahanan dan Jaminan Sosial } \\
\text { Wajib }\end{array}$ & 2.38 & 2.32 & 2.29 & Lebih kecil \\
P & Jasa Pendidikan & 2.99 & 3.05 & 2.11 & Lebih kecil \\
Q & Jasa Kesehatan dan Kegiatan Sosial & 0.68 & 0.71 & 0.74 & Lebih kecil \\
R,S,T,U & Jasa Lainnya & 1.52 & 1.54 & 1.58 & Lebih kecil \\
& & & & & \\
PRODUK DOMESTIK REGIONAL BRUTO & 9.83 & 9.11 & 8.98 & \\
\hline
\end{tabular}

Sumber: Badan Pusat Statistik Kabupaten Cilacap, 2018, data diolah

Tabel 8.

Hasil Analisis Klassen Tipologi Pendekatan Sektoral Kab Cilacap

\begin{tabular}{|c|c|c|c|c|c|c|c|}
\hline $\begin{array}{l}\text { Kate } \\
\text { gori }\end{array}$ & Uraian & $\begin{array}{l}\text { perbandingan } \\
\text { Dengan Laju } \\
\text { Pertumbuhan } \\
\text { PDRB }\end{array}$ & $\begin{array}{l}\text { Perbandingan } \\
\text { Dengan } \\
\text { Distribusi } \\
\text { PDRB }\end{array}$ & $\begin{array}{l}\text { kwadr } \\
\text { an i } \\
\text { unggul } \\
\text { an }\end{array}$ & $\begin{array}{l}\text { kwadran } \\
\text { ii } \\
\text { berkemba } \\
\text { ng }\end{array}$ & $\begin{array}{l}\text { kwadr } \\
\text { an iii } \\
\text { potens } \\
\text { ial }\end{array}$ & $\begin{array}{l}\text { kwadra } \\
\text { n iv } \\
\text { terbelak } \\
\text { ang }\end{array}$ \\
\hline A & $\begin{array}{l}\text { Pertanian, Kehutanan dan } \\
\text { Perikanan }\end{array}$ & Lebih kecil & Lebih besar & & & A & \\
\hline B & $\begin{array}{l}\text { Pertambangan dan } \\
\text { Penggalian }\end{array}$ & Lebih kecil & Lebih kecil & & & & B \\
\hline $\mathrm{C}$ & Industri Pengolahan & Lebih kecil & Lebih besar & & & $\mathrm{C}$ & \\
\hline $\mathrm{D}$ & Pengadaan Listrik dan Gas & Lebih besar & Lebih kecil & & $\mathrm{D}$ & & \\
\hline $\mathrm{E}$ & $\begin{array}{l}\text { Pengadaan Air, Pengelolaan } \\
\text { Sampah, Limbah dan Daur } \\
\text { Ulang }\end{array}$ & Lebih besar & Lebih kecil & & $\mathrm{D}$ & & \\
\hline $\mathrm{F}$ & Konstruksi & Lebih besar & Lebih besar & $\mathrm{F}$ & & & \\
\hline $\mathrm{G}$ & $\begin{array}{l}\text { Perdagangan Besar dan } \\
\text { Eceran, Reparasi Mobil dan } \\
\text { Sepeda Motor }\end{array}$ & Lebih besar & Lebih besar & G & & & \\
\hline $\mathrm{H}$ & $\begin{array}{l}\text { Transportasi dan } \\
\text { Pergudangan }\end{array}$ & Lebih besar & Lebih kecil & & $\mathrm{H}$ & & \\
\hline I & $\begin{array}{l}\text { Penyediaan Akomodasi dan } \\
\text { Makan Minum }\end{array}$ & Lebih besar & Lebih kecil & & I & & \\
\hline $\mathrm{J}$ & Informasi dan Komunikasi & Lebih besar & Lebih kecil & & $\mathrm{J}$ & & \\
\hline K & Jasa Keuangan dan Asuransi & Lebih besar & Lebih kecil & & K & & \\
\hline $\mathrm{L}$ & Real Estate & Lebih besar & Lebih kecil & & $\mathrm{L}$ & & \\
\hline $\mathrm{M}, \mathrm{N}$ & Jasa Perusahaan & Lebih besar & Lebih kecil & & MN & & \\
\hline $\mathrm{O}$ & $\begin{array}{l}\text { Administrasi Pemerintah, } \\
\text { Pertahanan dan Jaminan } \\
\text { Sosial Wajib }\end{array}$ & Lebih besar & Lebih kecil & & $\mathrm{O}$ & & \\
\hline$P$ & Jasa Pendidikan & Lebih besar & Lebih kecil & & $P$ & & \\
\hline
\end{tabular}




\begin{tabular}{clclc}
\hline Q & $\begin{array}{l}\text { Jasa Kesehatan dan Kegiatan } \\
\text { Sosial }\end{array}$ & Lebih besar & Lebih kecil & Q \\
R,S, Jasa Lainnya & Lebih besar & Lebih kecil & \\
T,U & & & R,S,T,U \\
\hline
\end{tabular}

Sumber: Badan Pusat Statistik Kabupaten Cilacap, 2018, data diolah

Tabel 9.

Kuadran Sektoral

\begin{tabular}{|c|c|c|}
\hline & Y Sektoral >PDRB & Y Sektoral < YPDRB \\
\hline 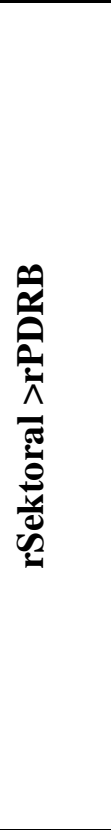 & \begin{tabular}{ll} 
& \multicolumn{1}{c}{ UNGGULAN } \\
1. & Konstruksi \\
2. & Perdagangan Besar dan \\
Eceran, Reparasi Mobil dan \\
Sepeda Motor
\end{tabular} & $\begin{array}{l}\text { BERKEMBANG } \\
\text { 1. Pengadaan Listrik dan Gas } \\
\text { 2. Pengadaan Air, Pengelolaan } \\
\text { Sampah, Limbah dan Daur Ulang } \\
\text { 3. Transportasi dan Pergudangan } \\
\text { 4. Penyediaan Akomodasi dan } \\
\text { Makan Minum } \\
\text { 5. Informasi dan Komunikasi } \\
\text { 6. Jasa Keuangan dan Asuransi } \\
\text { 7. Real Estate } \\
\text { 8. Jasa Perusahaan } \\
\text { 9. Administrasi Pemerintah, } \\
\text { Pertahanan dan Jaminan Sosial } \\
\text { Wajib } \\
\text { 10. Jasa Pendidikan } \\
\text { 11. Jasa Kesehatan dan Kegiatan } \\
\text { Sosial } \\
\text { 12. Jasa Lainnya }\end{array}$ \\
\hline 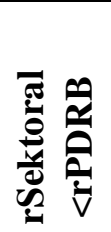 & $\begin{array}{l}\text { POTENSIAL } \\
\text { 1. Pertanian, Kehutanan dan } \\
\text { Perikanan } \\
\text { 2. Industri Pengolahan }\end{array}$ & $\begin{array}{l}\text { TERBELAKANG } \\
\text { 1. Pertambangan dan Penggalian }\end{array}$ \\
\hline
\end{tabular}

Sumber: Badan Pusat Statistik Kabupaten Cilacap, 2018, data diolah

\section{STRATEGI PENINGKATAN DAYA SAING DAERAH}

Daya Saing daerah adalah kemampuan sektor lembaga dan atau bisnis/perusahaan pada suatu daerah untuk dapat menghasilkan pendapatan yang tinggi serta tingkat kekayaan yang lebih merata untuk penduduknya. Daya Saing ini akan ditopang pada lima macam sumber ekonomi, yaitu energi, pertanian, perdagangan, jasa dan industri.
Jika melihat dari hasil Analisis Tipologi Klassen maka bisa disimpulkan Kabupaten Cilacap adalah kabupaten Perdagangan, konstruksi dan Industri. Tanpa mengesampingkan adanya potensi pertanian dan perikanan serta industri pengolahan, maka 3 sektor itulah yang sebaiknya menjadi fokus perhatian pemerintah daerah ketika menentukan strategi dan mengambil kebijakan. 


\section{Analisis Hasil Tipologi Klassen Sektor Unggulan}

Sektor unggulan merupakan sektor dengan laju pertumbuhan sektor yang lebih besar dibandingkan pertumbuhan daerah (PDRB) dan memiliki kontribusi besar terhadap PDRB.

Tabel 11.

Sektor Unggulan

\begin{tabular}{|c|c|c|}
\hline No & Sektor & Strategi \\
\hline 1 & Konstruksi & $\begin{array}{l}\text { Mempertahankan laju pertumbuhan dan kontribusi terhadap PDRB } \\
\text { dengan secara kontinyu terus mengupayakan membuka pintu-pintu } \\
\text { kerjasama dengan dunia luar disertai dengan peningkatan Kualitas } \\
\text { Teknis dan Ekonomis dengan memberikan pelatihan kepada para } \\
\text { pelaku usaha konstruksi dan menfasilitasi sertifikasi bagi tenaga- } \\
\text { tenaga kontruksi }\end{array}$ \\
\hline 2 & $\begin{array}{l}\text { Perdagangan } \\
\text { Besar dan } \\
\text { Eceran, } \\
\text { Reparasi } \\
\text { Mobil dan } \\
\text { Sepeda } \\
\text { Motor }\end{array}$ & $\begin{array}{l}\text { Mempertahankan laju pertumbuhan dan kontribusi terhadap PDRB } \\
\text { dengan mempertahankan dan meningkatkan kualitas serta kuantitas } \\
\text { produk dan penjualan Meningkatkan Laju Pertumbuhan dengan } \\
\text { membuka peluang-peluang pemasaran yang lebih luas Peningkatan } \\
\text { kualitas sentra perdagangan /pasar. } \\
\text { Meningkatkan pelayanan pelaku jasa reparasi dengan cara } \\
\text { pelatihan manajemen dan non manajemen. }\end{array}$ \\
\hline
\end{tabular}

Sumber : BPS Kabupaten Cilacap dan BPS Jawa Tengah, 2018, diolah

Pertumbuhan jumlah pasar tempat terjadinya transaksi perdagangan dari tahun 2015 hingga 2017 masih sama. Menguatnya system online dalam bertransaksi menjadi salah satu sektor unggulan dari Kabupaten Cilacap ini tidak lagi berkembang. Penelitian (Husna et al., 2018) Hasil dari penelitian ini menyebutkan bahwa sektor yang paling potensial dikembangkan di Kabupaten Gresik yaitu, sektor industri pengolahan; listrik, gas, dan air bersih; serta sektor pertambangan dan penggalian sedang di Kabupaten Cilacap sektor konstruksi dan perdagangan. Setiap daerah mempunyai potensi sendiri-sendiri sesuai dengan sumber daya alam dan sumber daya manusia dan potensi lain yang dimiliki.

Menurut Yoga \& Nurmahdi, (2018) Pemasaran digital (atau juga disebut pemasaran internet atau pemasaran online) diasosiasikan dengan pemasaran langsung karena perusahaan-perusahaan yang melakukan kegiatan pemasaran digital ini dapat memperpendek supply chain atau rantai pasokannya dan tentunya dapat mengurangi biaya operasionalnya. Jika digabungkan antara kegiatan pemasaran digital dan perilaku konsumen secara online dengan kesadaran akan merek, ketiga hal ini dapat mempengaruhi pengambilan keputusan pembelian konsumen secara online terhadap suatu produk atau jasa. Produk yang diteliti dalam penelitian ini dalam kaitannya dengan pemasaran digital dan perilaku online konsumen.

Keberhasilan dalam meningkatkan ekspor juga menunjukkan peningkatan daya saing dan sekaligus merupakan 
indikator dari pertumbuhan dinamika positif dalam kewirausahaan suatu negara atau daerah. Peningkatan ekspor bukan lagi sekedar pilihan melainkan sebuah keharusan. Pemasaran produk di luar negeri berbeda dengan memasarkannya di dalam negeri. Pasa luar negeri sangat kompetitif sehingga hanya pengusaha yang mampu bersaing dan punya daya saing tinggi yang akan menang dalam persaingan dan berhasil mendapatkan pangsa pasar.

Usaha untuk menciptakan daya saing dilakukan dengan meningkatkan perbaikan mutu produk ekspor hal ini dilakukan untuk menghindari adanya penolakan dari negara tujuan ekspor. Keberhasilan dalam perdagangan internasional suatu negara dapat ditunjukkan dari daya saingnya, daya saing ini merupakan suatu konsep umum dimana yang digunakan dalam ekonomi, merujuk pada komitmen terhadap persaingan pasar dan kesuksesannya dalam persaingan internasional.

Daya saing merupakan kunci bagi perusahaan, negara maupun wilayah untuk dapat berhasil dalam partisipasinya dalam globalisasi dan perdagangan bebas dunia. Mengetahui potensi daerah menjadi hal yang penting untuk mengembangkan potensi yang ada (Sucahyowati \& Hendrawan, 2020).

Terdapat tiga hal yang perlu dipertimbangkan dalam persaingan internasional khususnya daya saing produk ekspor Amir (2003) dalam Bustomi (2013) tiga hal tersebut adalah sebagai berikut :

1. Harga, ketika menawarkan sesuatu produk harga haruslah sama atau lebih rendah dibandingkan harga yang ditawarkan pesaing, atau biaya produksi lebih rendah dari biaya produksi di negara tujuan. Negara pengekspor memiliki keunggulan komparatif.

2. Kualitas Produk, Kualitas harus memenuhi atau sesuai dengan selera konsumen.

3. Waktu Pengiriman, pengiriman harus disesuaikan dengan situasi dan kondisi pasaran di negara tujuan. Keterlambatan pengapalan dan pengiriman barang dapat berakibat fatal, hal ini disebabkan produk tersebut tidak lagi dijual pada akhirnya akan mengurangi minat dan permintaan akan produk tersebut.

Menurut penelitian Hendrawan, Kuswantoro, \& Sucahyowati, (2019) kreativitas menjadi hal yang utama dalam meningkatkan daya saing, UMKM akan berkembang sehingga menghasilkan produk produk yang diminati pasar. Bagaimanapun semua tidak bisa bekerja sendiri (Hendrawan, 2018; Hendrawan, Yulianeu, et al., 2018) harus kerja sama tim yang solid agar tercipta pemasaran yang sukses sebagai ujung tombak keberhasilan (Hendrawan, Sucahyowati, et al., 2019).

Peningkatan daya saing dapat dilakukan dengan perubahan perilaku antara lain dengan perilaku organizational citizenship behavior (OCB) (Hendrawan, Indriyani, Sucahyowati, \& Cahyandi, 2020; Hendrawan, Laras, Sucahyowati, \& Cahyandi, 2020; Hendrawan, Sucahyawati, \& Cahyandi, 2018; Hendrawan, Sucahyowati, Reyendra, \& Indriyani, 2019;), perilaku OCB akan mengubah organisasi bahkan masyarakat menjadi lebih peduli kepada sesama dan kinerja meningkat sehingga produktivitas meningkat yang ujungnya pada peningkatan daya saing (Hendrawan, Sucahyowati, Cahyandi, et al., 2020). 


\section{SIMPULAN}

Berdasarkan analisa tipologi klassen maka disimpul kan temuannya adalah sektor unggulan Kabupaten Cilacap adalah sektor konstruksi serta sektor perdagangan besar dan eceran, reparasi mobil dan sepeda motor, hal ini sangat memungkinkan karena Kabupaten Cilacap merupakan kota industri sehingga kegiatan konstruksi menjadi salah satu andalan Kabupaten Cilacap. Kontribusi yang cukup besar juga diberikan sektor perdagangan dan eceran. Meskipun jumlah pasar dan swalayan tidak berubah dari tahun 2015 hingga 2017 namun sektor ini juga menjadi unggulan. Peningkatan kinerja dan produktivitas yang unggul bisa dilakukan dengan perubahan perilaku organizational citizenship behavior (OCB).

\section{DAFTAR PUSTAKA}

Ariyanto, D. C. (2013). Analisis Daya Saing Sektor Unggulan Dalam Struktur Perekonomian Provinsi Jawa Tengah Tahun 2010. Fakultas Ekonomi Universitas Diponegoro Semarang.

Badan Pusat Statistik Kabupaten Cilacap. (2018). Kabupaten Cilacap Dalam Angka Cilacap Regency In Figures. Bps Kabupaten Cilacap/Bps-Statistics Of Cilacap, 5214.

Bapeda Kab Banyuwangi. (2015). Penyusunan Kajian Peningkatan Daya Saing Daerah Kabupaten Banyuwangi. Badan Perecanaan Pembangunan Daerah Banyuwangi.

Hendrawan, A. (2018). Pengembangan Kompetensi Umkm Dengan Pembelajaran Organisasi. Jurnal Inovasi Bisnis Dan Manajemen Indonesia, 1(4), 489-496.

Hendrawan, A., Kuswantoro, F., \& Sucahyowati, H. (2019). Dimensi Kreativitas Dan Pengembangan Usaha Mikro Kecil Dan Menengah ( Umkm ). Jurnal Hummansi, 2(1), 25-36.

Hendrawan, A., Laras, T., Sucahyowati, H., \& Cahyandi, K. (2020). Peningkatan Kepemimpinan Transformasional Dengan Organizational Citizenship Behavior (Ocb. $1-16$.

Hendrawan, A., Sucahyawati, H., Cahyandi, K., Indriyani, \& Lusiani. (2018). Hubungan Pendidikan Dan Organizational Citizenship Behavior (Ocb) Terhadap Indikator Keselamatan Nelayan. Prosiding Seminar Nasional Universitas Pekalongan "Job Outlook Mencari Atribut Ideal Lulusan Perguruan Tinggi. Https://Doi.Org/10.1017/Cbo9781107415324.004

Hendrawan, A., Sucahyawati, H., Reyendra, A., \& Indriyani. (2019). Organizational Citizenship Behavior (Ocb) Dan Keleleahan Kerja Pada Nelayan. Amanu: Jurnal Manajemen Dan Ekonomi, 2(2), 135-155.

Hendrawan, A., Sucahyowati, H., \& Cahyandi, K. (2020). Avoid Leadership Pengaruhnya Terhadap Kinerja Dan Organizational Citizenship Behavior (Ocb). 7thncab 2020 National Conference Applied Business, .

Hendrawan, A., Sucahyowati, H., Cahyandi, K., \& Indriyani, I. (2020). Motivasi Kerja Dan Organizational Citizenship Behavior Pada Karyawan Pt Mk Semarang. Jurnal Administrasi Dan Kesekretarisan, 5(1), 74-87.

Hendrawan, A., Sucahyowati, H., Cahyandi, K., Indriyani, \& Rayendra, A. (2019). Pengaruh Marketing Digital Terhadap Kinerja Penjualan Produk Umkm Asti Gauri Di 
Kecamatan Bantasari Cilacap. Jurnal Administrasi Dan Kesekretarisan, 4(1), 53-60. Http://Www.Jurnal.Stiks-Tarakanita.Ac.Id/Index.Php/Jak/Article/View/189/136

Hendrawan, A., \& Yulianeu, A. (2017). Organizational Citizenship Behavior (Ocb) Pada Nelayan. Prosiding Seminar Idri, 1(1), 1-11.

Hendrawan, A., Yulianeu, A., \& Cahyandi, K. (2018). Pengaruh Kompetensi Terhadap Kinerja Tim. Journal Of Management Review, 2(1), 143. Https://Doi.Org/10.25157/Jmr.V2i1.1116

Husna, N., Noor, I., \& Rozikin, M. (2018). Analisis Pengembangan Potensi Ekonomi Lokal Untuk Menguatkan Daya Saing Daerah Di Kabupaten Gresik. Jurnal Administrasi Publik (Jap), 1(1), 188-196.

Irawati, I., Urufi, Z., Resobeoen, R. E. I. R., Setiawan, A., \& Aryanto. (2012). Pengukuran Tingkat Daya Saing Daerah Berdasarkan Variabel Perekonomian Daerah, Variabel Infrastruktur Dan Sumber Daya Alam, Serta Variabel Sumber Daya Manusia Di Wilayah Provinsi Sulawesi Tenggara. J@Ti Undip, 7(1), 43-50.

Malhotra. (2004). Essentials Of Marketing Research: An Applied Orientation. Pearson Education Australia.

Rajagukguk, W. (2018). Daya Saing (Competitiveness) Mendorong Pertumbuhan Ekonomi Sebuah Negara: Studi Kasus Negara Berkembang. Program Pascasarjana Universitas Kristen Indonesia. Https://Doi.Org/10.13140/Rg.2.2.32248.55043

Sucahyowati, H., \& Hendrawan, A. (2020). Sedimentasi Dan Perembangan Perekonomian Di Wilayah Pesisir Studi Kasus Desa Penikel. Wijayakusuma Prosiding Seminar Nasional: Jaringan Penelitian (Jarlit) Cilacap "Menuju Cilacap 4.C (Creativity, Critical Thingking, Communication And Colaboration)," 1(1). Https://Doi.Org/10.1017/Cbo9781107415324.004

Yoga, H., \& Nurmahdi, A. (2018). Pengaruh Kegiatan Pemasaran Digital Dan Perilaku Online Konsumen Pada Peningkatan Kesadaran Konsumen Dan Dampaknya Terhadap Keputusan Pembelian Via Website.Harwindra_Yoga@Yahoo.Com Dan. 